\title{
MANAJEMEN KOMUNIKASI DI CALL CENTER TELKOM 147 KOTA SEMARANG
}

\author{
Aditiya Rezananda, Arie Prasetio \\ Universitas Telkom
}

\begin{abstract}
ABSTRAK
Komunikasi merupakan hal yang penting di era saat ini ,hal ini terjadi karena dengan komunikasi manusia mampu mempenuhi kebutuhan hidupnya dalam menjalankan kegiatan aktivitas sehari-hari. Dalam penelitian ini peneliti meneliti bagaimana komunikasi antar pribadi antara konsumen Indi Home dengan call center Telkom 147 mempengaruhi kesuksesan pesan yang akan disampaikan konsumen. Manajemen Komunikasi secara umum dipahami sebagai peroses mengordinasikan interpretasi atau pengertian melalui interaksi antar manusia. Kemampuan berkomunikasi dalam interaksi ini dipengaruhi oleh sudut pandang pengalaman individu ( field of experiance) dan kerangka berpikir yang dipahami oleh konsumen. Penelitian ini bertujuan untuk mengetahui bagaimana manajemen komunikasi yang terjadi di dalam call center Telkom 147 Kota Semarang. Penelitian ini menggunakan metodologi pendekatan kualitatif studi kasus serta didukung oleh paradigma konstruktivisme. Data pada penelitian ini diperoleh melalui wawancara langsung dengan tiga orang dari Pihak call center Telkom 147 Kota Semarang sebagai informan utama dan 2 pelanggan Indi Home sebagai informan pendukung serta studi dokumentasi data. Hasil penelitian ini adalah untuk mengetahui Manajemen Komunikasi yang terdapat didalam call center Telkom 147 Kota semarang menggunakan elemen-elemen manajemen komunikasi yakni self, interpersonal, people in system dan competance.
\end{abstract}

Kata-kata Kunci: Manajemen, Komunikasi, Micheale Kaye, Call Center, Telkom 147 Kota Semarang

COMMUNICATION MANAGEMENT IN THE CALL CENTER 147 OF SEMARANG CITY

\begin{abstract}
Communication is crucial in the current era, this happens because human communication is able to meet the needs of his life in carrying out daily activities. In this study researchers examine how interpersonal communication between consumers Indi Home with Telkom Call Center 147 affect success messages to be delivered to consumer. Communication management is generally understood as a process of interpretation or understanding through the interaction between human. The ability to communicate in these interactions are influenced by the viewpoint of individual experience (field of experiance) and frame of mind that is understood by the consumer. This research aims to find out how the management of communication goes on in Telkom Call Center 147 semarang. This research used the qualitative case study approach methodology and supported by the paradigm of constructivism. The research on data obtained through direct interviews with three people from the Telkom Call Center 147 Semarang as the primary informant and 2 customers indihome as informants as well as the supporting documentation study data. The results of this research is to know the communication management contained in Telkom Call Center 147 semarang city using elements of communication management i.e. interpersonal, self, people in system and competance.
\end{abstract}

Keywords: Management,Communication, Micheale Kaye, Call Center, Telkom 147 of Semarang City.

Korespondensi: Aditiya Rezananda. Universitas Telkom. Jl. Telekomunikasi No. 01, Terusan Buah Batu, Bandung, Jawa Barat 40257. Email: rezanandaa@gmail.com 


\section{PENDAHULUAN}

Komunikasi merupakan hal yang penting di era saat ini ,hal ini terjadi karena dengan komunikasi manusia mampu mempenuhi kebutuhan hidupnya dalam menjalankan kegiatan aktivitas sehari-hari. Istilah komunikasi berasal dari kata latin "communicare" yang berarti memberitahukan atau berpartisipasi (Sugiyo, 2005: 1). Sedangkan (Cangara, 1998: 20) mengemukakan bahwa komunikasi adalah suatu proses dimana dua orang atau lebih membentuk atau melakukan pertukaran informasi dengan satu sama lainnya, yang pada gilirannya akan tiba pada saling pengertian yang mendalam.

Dalam penelitian ini peneliti meneliti bagaimana komunikasi antar pribadi antara konsumen Indi Home dengan call center Telkom 147 mempengaruhi kesuksesan pesan yang akan disampaikan konsumen. Karena dalam hal ini kecakapan dalam berkomunikasi dimana pesan yang di sampaikan harus jelas. Namun terkadang dikarenakan faktor kompetensi komunikasi konsumen maupu operator dalam menyampaikan dan menanggapi keluhan dari konsumen tersebut maka terkadang timbulah miss comunication dimana terdapat banyak faktor yang mempengaruhi antara lain bisa berupa aspek emosional dari konsumen hingga faktor pelayanan yaitu manajemen komunikasi yang dimiliki oleh operator call center Telkom 147 tidak sesuai dengan standar operasional prosedur (SOP) sehingga memeberikan pelayanan atau feedback yang tidak sesuai dengan keinginan konsumen .
Hsin, Huery \& Cheng (2008) dalam Renata (2016) menyatakan bahwa apabila pelanggan puas terhadap pelayanan yang diterima, maka akan menimbulkan kesetiaan konsumen. Dengan kesetiaan konsumen terhadap produk atau layanan tersebut akan membuat konsumen kembali melakukan transaksi di masa datang.

Dalam melakukan penyampaian keluhan yang dilakukan konsumenya. PT.Telekomunikasi Indonesia dituntut untuk semaksimal mungkin memberi layanan prima kepada para pelanggan Telkom itu sendiri antara lain dengan cara persuasif pelanggan dan menangani komplain pelanggan. Hal tersebut bukan merupakan sesuatu yang mudah karena komunikasi yang terjadi antara perusahaan Telkom Indonesia yang diwakili oleh PT Infomedia Nusantara dengan pelanggan di lakukan dengan komunikasi secara tidak langsung namun melalui sebuah media atau pesawat telepon. Sehingga dibutuhkan sebuah kemampuan atau keterampilan berkomunikasi yang baik.

Keluhan-keluhan tersebut seluruhnya akan di layani oleh anak perusahaan PT.Telekomunikasi Indonesia yakni PT. Infomedia Nusantara yang melayani seluruh keluhan Tehadap layanan maupun produk Telkom. Dalam hal ini keluhan dikelola melalui alur manajemen komunikasi mengambil peranan yang besar pada hal ini dimana keluhan dikelola melalui saluran yang telah di tentukan melalui standar operasional prosedur (SOP) sehingga tidak akan terjadi miss komunikasi dan tanggapan keluhan melalui sumber-sumber berbeda. 


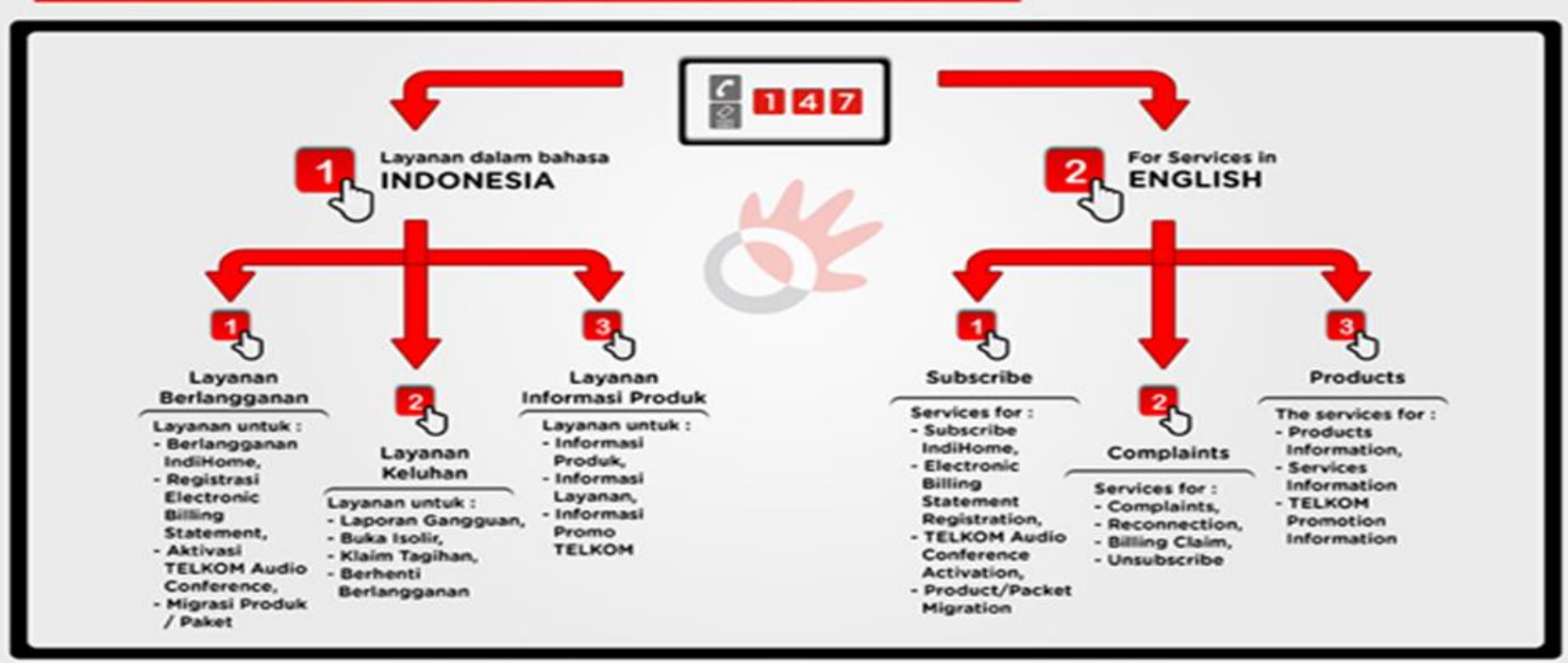

Selain Contact Center 147, Pelanggan dapat juga berinteraksi melalui :

صmail CustomerCaregtelkom.coid dan Social Media : 9 @elkomCare dan $\mathbf{n}$ TelkomCare

Gambar 1 Alur Pelayanan Contact Center 147

Sumber: https://my.telkom.co.id/knowledge-base/index.php?pID=186

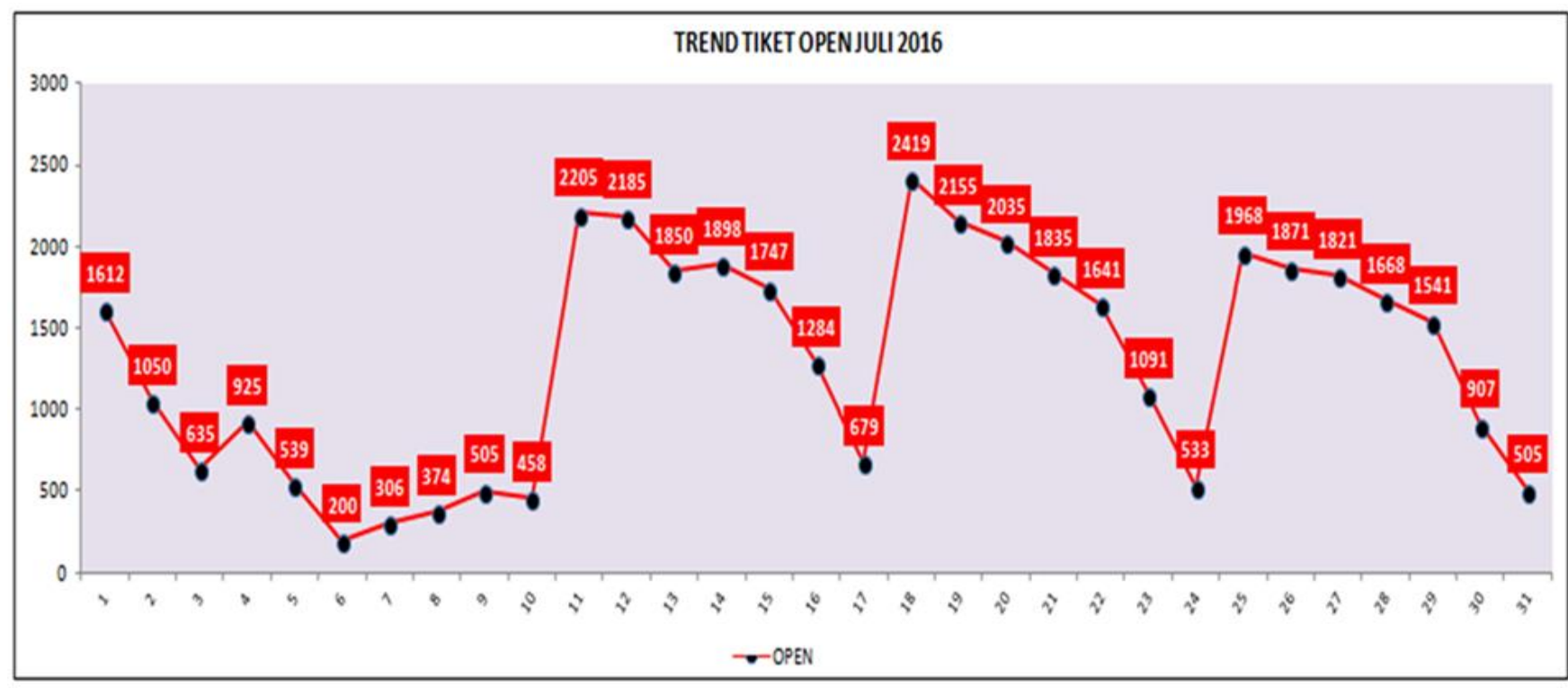

Gambar: 2 Grafik Pengaduan Telkom 147 Regional IV Jateng \& DIY Bulan Juli 2016 Sumber:https://nonatero.telkom.co.id 


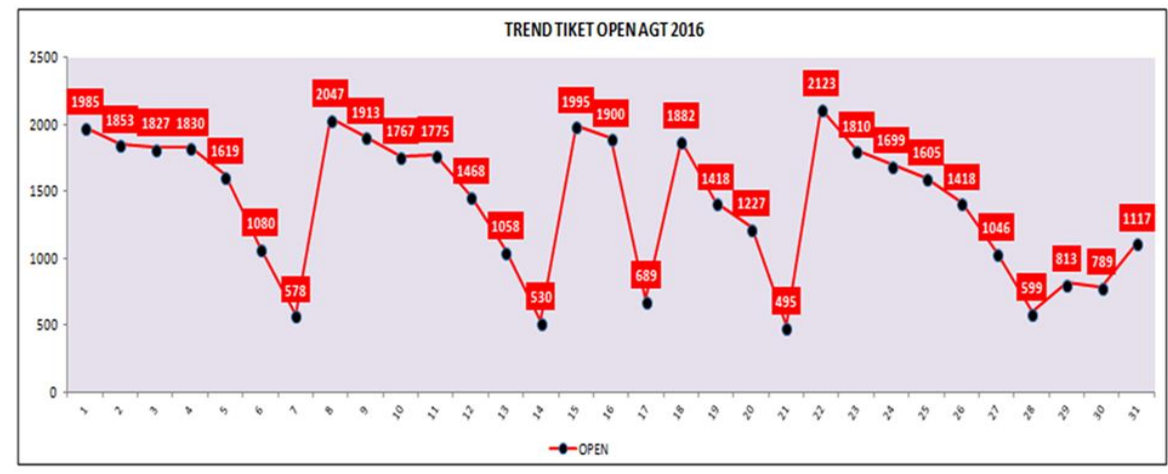

mengenai suatu permasalahan hukum, sosial, politik, budaya, komunikasi, pemasaran, PR, dan tentang pelayanan publik lainnya yang pernah dimuat berbagai media cetak seperti jurnal, majalah dan surat kabar, atau media publikasi

Gambar: 3 Grafik Pengaduan Telkom 147 Regional IV Jateng \& DIY Bulan Agustus 2016 Sumber:https://nonatero.telkom.co.id

\section{Menurut Indonesia Contact Center} Association. Yang dikutip melalui http://icca.co.id. PT.Infomedia Nusantara, salah satu anak perusahaan PT.Telkom Indonesia berhasil meraih predikat ke 2 The Best Contact Center 2016. Dalam Hal ini perlu dilakukan penelitian ini karena solusi belum dianggap sukses karena dengan penghargaan The Best Contact Center 2016 yang diadakan oleh Indonesia Contact Center Association. call center Telkom 147 masih menempati urutan ke- 2 dibawah Bank Bca Sehingga dengan banyaknya penghargaan yang diraih oleh operator Telkom 147, namun dalam pengaduan sehari-hari menunjukan grafik peningkatan setiap bulannya dikarenakan konsumen belum menerima feedback sesuai yang diharapkan. Tujuan dari penelitian ini untuk mengetahui Manajemen Komunikasi Di Call

\section{Center Telkom 147 Kota Semarang.}

\section{METODE}

Penelitian ini menggunakan metode studi kasus kualitatif. Penelitian eksploratoris ini dapat dilakukan dengan mempelajari melalui catatancatatan dari kasus-kasus tertentu (case recorded) internal di pusat pelayanan publik, seperti kantor catatan sipil, kantor polisi, kantor pos, rumah sakit, yayasan YLKI dan Lembaga Swadaya Masyarakat(LSM) lainnya sebagai sumber informasi,data, dan bahan-bahan materi untuk melakukan kegiatan penelitian. Pemilihan catatan kasus tersebut, di dalam studi kasus ini sama dengan survei pengalaman dengan tidak mempergunakan sampling tertentu (Ruslan, 2010: 11).

\section{HASIL DAN PEMBAHASAN}

\section{Proses Komunikasi}

Schramm (1955) yang dikenal sebagai bapak komunikasi mengembangkan secara umum model komunikasi tersebut berdasarkan komponen-komponen dari model komunikasi linier. Didalam call center Telkom 147 Kota Semarang. Menggunakan model komunikasi linier proses komunikasi yang dilakukan dengan menggunakan Signal: the transmission of the message using patricular media (pengiriman pesan dengan menggunakan media) yaitu pesan di kirimkan menggunakan media telepon yakni dengan menghubungi call center Telkom 147 Kota Semarang dan yang berperan sebagai Source: the individual or organisation sending the messages 
(pengrim pesan yaitu individu atau organisasi) yakni pelanggan Indi Home dan Receiver: the individual or organisation receiving the message (individu atau organisasi penerima pesan) yakni Operator Telkom 147 Kota Semarang.

Hambatan yang dialami yakni Noise: distortion of the communication process, making it difficult for the receiver to interpret message intended by the source. (distorsi dari proses komunikasi, yang membuat penerima berbeda dalam mengintepretasikan pesan) yakni diantaranya terjadi diakibatkan oleh pesan yang disampaikan tidak dapat tertangkap dengan jelas oleh operator contohnya suara nya kecil, kemrosok dan suaranya terputus-putus sehingga akan mengakibatkan telepon berulang dan faktor peralatan pendukung operator call center Telkom 147 terganggu misal, gangguan pada saluran telepon sehingga akan menimbulkan noise kemudian agen operator tidak menguasai produk yang di jual ke konsumen serta menggunakan bahasa yang terlalu teknis sehingga tidak dapat dimengerti oleh konsumen dan akan menimbulkan noise yaitu membuat penerima berbeda dalam mengiterpretasikan pesan.

\section{Manajemen Komunikasi yang terjadi di dalam}

\section{Call Center Telkom 147 Kota Semarang.}

Seperti yang telah dipaparkan sebelumnya, teori manajemen komunikasi yang digunakan adalah model manajemen komunikasi menurut Michaeal Kaye yang dianggap relevan oleh penulis karena pada fokus pertanyaan penelitian ini, penulis ingin mengetahui bagaimana proses manajemen komunikasi yang terjadi didalam call cennter Telkom 147 kota semarang. Untuk itu, dalam menganalisis proses komunikasi dan keterkaitan antara manajemen komunikasi dengan penanganan keluhan pelanggan Indi Home teori model manajemen komunikasi yang terdapat beberapa komponen yang terdapat didalam model manajemen komunikasi menurut Michaeal Kaye antara lain yakni self (diri sendiri), interpersonal, People in system, competance.

\section{Diri Sendiri (Self)}

Ukuran boneka terkecil, mewakili diri (self). Pengetahuan dan pemahaman tentang self seseorang sangat diperlukan untuk menuju pada tahap keberhasilan pengelolaan diri (selfmanagement) orang tersebut. 10 Kesadaran diri (self-awareness) merupakan dasar bagi analisis diri (selfanalysis) dan pengujian diri (self-examination) (Kaye, 1994: 10 - 11).

Dalam hasil wawancara dan dari dokumentasi data peneliti menyimpulkan bahwa agen operator yang dalam Call Center Telkom 147 sudah mempunya kampuan Self (diri sendiri) teori ini merupakan bagian dari pengetahuan ,Self Management, Self Awernes, Self analisis dan selfexamilation dalam hal ini agent operator call center Telkom 147 Kota semarang dapat disimpulkan dalam hal pengetahuan maupun kemampuan dasar yang harus dimiliki oleh agent call center Telkom 147 Kota Semarang berupa persyaratanpersyaratan yang harus di punyai oleh seluruh agent pertama administratif S1,D3 dan IPK kemudian masuk ke tahap tes kecerdasan lalu tes 
psiko kepribadian kemudian masuk kepada tahap interview kemudian masuk kedalam training include recruitment dimana dalam masa ini calon agent diasah kemampuan dasar yang dimilikinya sebagai calon agent seperti kemampuan berbicara, kepribadian, kedisiplinan serta integritasnya serta yang paling penting diasah skill komunikasinya.

Kemampuan dasar yang harus dimiliki berupa meaning voice serta harus mempunyai sikap cekatan dalam menanggulangi keluhan. Selain kemampuan dalam bahasa harus mempunyai kemampuan seperti hard skill,soft skill dan pengetahuan atas produk-produk dari PT Telkom itu sendiri. Kemampuan dasar yang harus dimiliki oleh agent sudah di tetapkan sesuai standart yang berlaku di call center Telkom 147 Kota Semarang kemudian untuk menyamakan kompetensi antara satu agent dengan agent yang lain dilakukan problem training serta problem brief sehingga antara satu agent dengan agent yang lain mempunyai kemampuan yang sama antara satu dengan yang lain atau mempunyai kompetensi dan kemampuan dasar yang sesuai dengan standart.

\section{Interpersonal}

Boneka interpersonal ini menggambarkan bagaimana komunikasi antar manusia dapat mempengaruhi satu sama lainnya dan bagaimana mereka berubah sebagai hasil interaksi di antara mereka (Kaye, 1994: 10 - 11). Dalam melakukan komunikasi interpersonal seorang operator call center Telkom 147 Kota Semarang di tuntut mempunyai atittude yang baik seperti dengan tidak memutus sambungan telefon dengan pelanggan dan juga tidak memotong pembicaraan jika pelanggan tengah melakukan pengaduan. Kemudian menjawab dengan cara mengenali karakteristik dari pelanggan yang mengadu Sehingga dengan mempunyai data base yang baik operator sudah bisa melakukan langkah-langkah yang diperlukan untuk menghandle keluhan yang diadukan oleh pelanggan. Setiap pengaduan pelanggan mempunyai karakteristik yang disimpulkan dalam sebuah listing TOP 10 ToP 5 yang berisi pertanyaan-pertanyaan yang paling sering dipertanyakan.

Hampir semua pertanyaan yang diadukan oleh konsuumen rata-rata mempunyai masalah yang sama tentang gangguan yang terjadi pada internet, telepon dan UseeTV pelanggan. Sehingga diharapkan dalam memberi jawaban yang terjadi didalam komunikasi interpersonal agent dapat menjawab sesuai dengan pertanyaan atau keluhan yang disampaikan oleh pelanggan sehingga dapat diharapkan terjadinya komunikasi yang baik antara konsumen dan agent serta agent dituntut untuk memecahkan masalah dengan baik sehingga terciptanya first call resolution di dalam percakapan yang terjadi. Kemudian menggunakan nada suara yang tidak meninggi dan menggunakan bahasa baku Sehingga komunikasi yang bersifat interpersonal dapat dimengerti oleh operator maupun pelanggan Indi Home yang melakukan pengaduan.

\section{People in system}

Dalam praktiknya, komunikasi adalah proses yang integral dalam menjalankan fungsifungsi manajemen secara sistematis, yang 
ditujukan untuk mencapai sasaran atau tujuan organisasi atau perusahaan. Dalam proses manajemen tersebut kegiatan komunikasi diaplikasikan melalui kegiatan yang berkaitan dengan aliran informasi yang sesuai dengan hierarki dalam struktur organisasi. Model hubungan antara proses manajemen dan proses komunikasi oleh Henry H.Albers (1974) dalam Soedarsono (2004).

Mengenali karakteristik keluhan pelanggan dimana dalam hal ini people in system harus berupaya mengetahui berdasarkan skema presedur yang berlaku didalam organisasi maupun system yang berlaku yang berada didalam call center Telkom 147 Kota Semarang sehingga dalam people in system komunikasi yang dilakukan antara pelanggan dengan operator Telkom 147 Kota Semarang dengan melibatkan standart operasional yang berada dalam system maupun organisasi Telkom 147 Kota Semarang. Bagaimana Karakteristik pelanggan dalam hal ini mempengaruhi kemampuan agent dalam mempengaruhi kosumen dan juga bagaimana sistem manusia atau organisasi akan mempengaruhi dengan cara melihat data pelanggan terlebih dahulu dengan menggunakan system jika memungkinkan agent memandu konsumen dalam menanggulangi problem yang diberikan konsumen kemudian jika tidak berhasil maka system akan melakukan langkah berikutnya yakni dengan menggunakan tiket dimana pelapor mendapatkan nomer pelaporan dan dilakukan langkah-langkah selanjutnya misalnya dengan memberi bantuan teknisi dalam mengatasi problem tersebut.

\section{Competence}

Dalam call center Telkom 147 operator di tuntut untuk mempunyai kemampuan yang selalu berkembang dikarenakan teknologi informasi dan komunikasi yang merupakan bisnis inti dari perusahaan Telkom yang selalui berkembang setiap saat dimana operator call center harus mengembangkan kemampuan dasar yang dimiliki. Dimana dalam hal ini kemampuan pribadi (self) harus dimiliki oleh semua operator call center Telkom 147 Kota Semarang seperti pengetahuan, kecakapan berkomunikasi dan kemampuan untuk mengambil keputusan dan solusi dalam bagian competance ini peneliti ingin mengetahui bagaimana kompetensi diri dan melakukan manajemen diri dalam hal ini setiap operator di tuntut untuk mempunyai peningkatan akan kemampuan diri.

Dalam meningkatkan kompetensinya dilakukan dengan cara training kemudian kalibrasi selanjutnya dilakukan yang dinamakan dengan quality control sebagai sarana untuk meningkatkan kompetensi dari operator call center Telkom 147 Kota Semarang. Peningkatan kompetensi yang utama dilakukan oleh call center Telkom 147 Kota Semarang dalam bentuk briefing 30 menit sesudah online dan 30 menit sebelum online kemudian dilakukan training untuk melakukan upgrated pengetahuan meliputi aplikasi maupun pengenalan produk-produk yang dijual oleh PT Telkom dan dalam hal peningkatan pelatihan dan peningkatan pengetahuan agen juga menjalankan praktek untuk mendapatkan pengalaman kinestetik 
Pola Jaringan Kerja Komunikasi Di Call Center

\section{Telkom 147 Kota Semarang.}

DeVito (1997: 344 - 345) mengaplikasikan jaringan kerja tersebut dalam beberapa bentuk struktur, yaitu. Struktur Roda, memiliki pemimpin yang jelas, posisi nya di pusat. Orang ini merupakan satu-satunya yang dapat mengirim dan menerima pesan dari semua anggota. Oleh karena itu, jika seorang anggota ingin berkomunikasi dengan anggota lain, maka pesannya harus disampaikan melalui pemimpinnya.

Dalam pertanyaan tersebut tentang pola jaringan kerja komunikasi yang terdapat dalam call center Telkom 147 Kota semarang yakni ketiga informan mempunyai jawaban yang sama dimana dalam setiap menjalani tugasnya agent diberikan otoritas dalam mengambil setiap keputusan dalam memberi solusi yang terjadi namun jika dalam kasus-kasus tertentu yang dalam hal ini agen tidak dapat memberikan solusi kepada pelanggan Indi Home yang mengadu maka akan dilaporkan kepada otoritas yang lebih tinggi yakni tim leader. Dalam hal ini call center Telkom 147 Kota Semarang menggunkan jaringan kerja komunikasi Struktur roda dimana dalam call center Telkom 147 Kota semarang berlaku komunikasi yang bersifat satu pintu dimana hanya pemimpim seperti tim leader yang dapat mengirim dan menerima pesan dari semua anggota.

Menurut (DeVito, 1997: 351), berbagai bentuk struktur jaringan kerja komunikasi tersebut merupakan sistem komunikasi umum yang digunakan oleh kelompok kerja untuk mengirimkan pesan antar anggota organiasi atau perusahaan. Struktur tersebut dalam organisasi atau perusahaan berupa kegiatan komunikasi formal yang dipergunakan sebagai sarana kegiatan komunikasi organisasi. Dalam hal ini jaringan kerja dalam komunikasi formal adalah desain sistem melalui manajemen untuk menetapkan siapa dan kepada siapa yang melaksanakan pekerjaan. Seluruh proses kegiatannya dilakukan sesuai dengan hierarki (jenjang) dalam struktur organisasi yang disebut sebagai kegiatan komunikasi ke atas dan ke bawah (vertikal atau diagonal) dan komunikasi ke samping (lateral atau horizontal). Komunikasi ke atas dimana aliran pesan dikirim dari tingkat hierarki nya yang lebih rendah ke tingkat yang lebih tinggi. Pada call center Telkom 147 Kota Semarang hierarki komunikasi bersifat vertikal semua komunikasi yang terjadi harus sepengetahuan tim leadernya.

\section{PENUTUP}

Proses Komunikasi yang terjadi di dalam call center Telkom 147 Kota semarang berlangsung dengan baik terlepas dari terdapatnya hambatan-hambatan dalam berkomunikasi dikarenakan komunikasi yang dilakukan oleh operator dan pelanggan Indi Home yang melakukan pengaduan ke call center Telkom 147 menggunakan sarana Telepon sehingga akan menimbulkan beberapa noise yang dapat mempengaruhi dalam pemaknaan dari pesan yang dikirimkan oleh operator atau yang biasa disebut dengan agen dengan pelanggan Indi Home.

Selanjutnya manajemen komunikasi yang berlangsung sudah diterapkan dengan baik didalam 
call center Telkom 147 Kota Semarang dimana komponen-komponen manajemen komunikasi sudah di terapkan dengan baik oleh call center Telkom 147 Kota Semarang.

Tim pelayanan Indi Home sebaiknya membuat sebuah buku petunjuk dan panduan untuk menyelesaikan problem secara pribadi yang dapat digunakan jika pelanggan Indi Home mengalami masalah atau gangguan pada layanan Indi Home pelanggan sehingga diharapkan dengan adanya buku petunjuk maupun segala informasi mengenai produk Indi Home tersebut diharapkan pelanggan akan menangani keluhan tersebut dengan personal sehingga tidak harus menghubungi call center Telkom 147 Kota Semarang jika mengalami gangguan dalam produk Indi Home yang digunakan.

\section{DAFTAR PUSTAKA}

Anisa,Renata .2016. Manajemen Kerelasian Pelanggan Dalam Menciptakan Kepercayaan Pelanggan Di Bank Mandiri Bandung.Unpad: Jurnal Kajian Komunikasi.Vol.4 No.1

Barker,Larry L.1987. Communication.United State of America: Prentice Hall..

Cangara, Hafied. 1998. Pengantar Ilmu komunikasi. Jakarta: Raja Grafindo Persada.

Devito, Joseph A. 1997. Komunikasi Antar Manusia. Jakarta:Professional Books.

Kaye, Michael. 1994. Communication Management. Sydney: Prentice Hall.

Morissan. 2009. Teori Komunikasi Organisasi. Jakarta: Ghalia Indonesia
Ruslan, Rosady .2010.Metode Penelitian Public Relations dan Komunikasi .Jakarta: Raja Grafindo Persada.

Schramm Wilbur.1955. The Process effects Of Mass Comunicatin. Urbana: University of Illinois Press.

Soedarsono,Dewi.2009. Sistem Manajemen Komunikasi.Bandung: Simbiosis.

Sugiyono. 2005. Metode Penelitian Kuantitatif Kualitatif Dan R\&D. Bandung :Alfabeta.

\section{Sumber Internet}

Telkom. 2016. Alur Pelayanan Contact Center 147. Diakses dari https://my.telkom.co.id/ knowledge-base/index.php?pID $=186$

Telkom. 2016. Grafik Pengaduan Telkom 147 Regional IV Jateng \& DIY Bulan Juli 2016. Diakses dari https://nonatero.telkom.co.id

Telkom. 2016. Grafik Pengaduan Telkom 147 Regional IV Jateng \& DIY Bulan Agustus $2016 . \quad$ Diakses dari https://nonatero.telkom.co.id

Contact Center Association. 2016. The Best Contact Center 2016. Diakses dari http://icca .co .id 